\title{
ANALISIS KESULITAN MAHASISWA DALAM MENYELESAIKAN SOAL PEMECAHAN MASALAH PADA MATA KULIAH ALJABAR DAN TRIGONOMETRI
}

\author{
Imelda \\ Universitas Katolik Santo Thomas Sumatera Utara \\ imelda_teach@yahoo.com
}

\begin{abstract}
The purpose of this study was to describe students' difficulties in solving problem solving problems in Algebra and Trigonometry courses. Subjects in this study were students of the Mathematics Education Faculty of Unika Santo Thomas Faculty of Teaching and Education study program in North Sumatra in semester 1 of the 2017-2018 school year, totaling 10 people. The data collection tool used in this study was a test of 5 questions in the form of a description. This type of research is a qualitative descriptive study. Data collection techniques are carried out by tests, observation, interviews and documentation. Data analysis techniques were carried out with the stages of data reduction, data presentation and conclusion drawing. The results showed that students had difficulty using the concept of equality and inequality squared, the use of the concepts of trigonometric formulas. Students also have difficulties in using number sequence principles and completing trigonometric equation solving, difficulties in disclosing information from problem solving and calculation errors. The contributing factor is the existence of several concepts and principles of algebra and trigonometry that are used in solving problems that have not been well controlled by students and are less thorough in performing calculations.
\end{abstract}

Keywords: Analysis of Learning Difficulties, Algebra and Trigonometry

\begin{abstract}
Abstrak. Tujuan dari penelitian ini adalah untuk mendeskripsikan kesulitan-kesulitan siswa dalam menyelesaikan soal pemecahan masalaha pada mata kuliah Aljabar dan Trigonometri. Subjek dalam penelitian ini adalah mahasiswa program studi Pendidikan Matematika Fakultas Keguruan dan Ilmu Pendidikan Unika Santo Thomas Sumatera Utara semester 1 tahun ajaran 2017-2018 yang berjumlah 10 orang. Alat pengumpulan data yang digunakan dalam penelitian ini adalah test yang berjumlah 5 soal berbentuk uraian. Jenis penelitian ini adalah penelitian deskriptif kualitatif. Teknik pengumpulan data dilakukan dengan tes, observasi, wawancara dan dokumentasi. Teknik analisis data dilakukan dengan tahap reduksi data, penyajian data dan penarikan kesimpulan. Hasil penelitian menunjukkan bahwa mahasiswa mengalami kesulitan penggunaan konsep persamaan dan pertidaksamaan kuadrat, penggunaan konsep rumus-rumus trigonometri. Mahasiswa juga kesulitan dalam penggunan prinsip barisan bilangan dan menyelesaikan penyelesaian persamaan trigonometri, kesulitan mengungkapkan informasi dari soal pemecahan masalah dan kesalahan perhitungan. Faktor penyebabnya adalah adanya beberapa konsep dan prinsip aljabar dan trigonometri yang digunakan dalam menyelesaikan masalah masih belum dikuasi dengan baik oleh mahasiswa dan kurang teliti dalam melakukan perhitungan.
\end{abstract}

Kata Kunci: Analisis Kesulitan Belajar, Aljabar dan Trigonometri

\section{PENDAHULUAN}

Matematika berkenan dengan ide-ide, struktur- struktur dan hubungan-hubungannya yang diatur menurut urutan yang logis. Jadi dapat dikatakan bahwa matematika berkenaan dengan konsep-konsep yang abstrak. Berkenaan dengan struktur abstrak, maka tidak jarang siswa atau mahasiswa mengalami kesulitan dalam memahami matematika atau bahkan dalam menyelesaikan soal-soal matematika di sekolah ataupun di tingkat perguruan tinggi.

Aljabar dan Trigonometri merupakan salah satu mata kuliah yang diajarkan di program studi pendidikan matematika. Dalam mempelajari mata kuliah Aljabar dan Trigonometri, mahasiswa diharapkan mampu memahami konsep Aljabar dan 
Trigonometri. Dalam 14 kali pertemuan tatap muka, maka mahasiswa akan memperoleh 7 pertemuan membahas materi Aljabar dan 7 pertemuan akan membahas materi Trigonometri. Setelah menyelesaikan mata kuliah, maka siswa memiliki keterampilan dalam menyelesaikan masalah matematika dalam bidang Aljabar dan Trigonometri. Dalam pembelajaran yang dilakukan, dosen melaksanakan pembelajaran dengan menerapkan model pembelajaran pemecahan masalah dimana mahasiswa diberikan soal-soal pemecahan masalah untuk diselesaikan dan disiskusikan.

Sebagian besar ahli pendidikan matematika menyatakan "masalah" merupakan pertanyaan yang harus dijawab. Namun tidak semua pertanyaan otomatis akan menjadi masalah. Suatu pertanyaan akan menjadi masalah hanya jika pertanyaan itu menunjukkan adanya suatu tantangan yang tidak dapat dipecahkan oleh prosedur rutin yang sudah diketahui pelaku (Fajar, 2009:5). Senada dengan pernyataan Suyadi (2009) juga menyebutkan bahwa ciri soal dikatakan "problem" paling tidak memuat dua hal yaitu: a) Soal tersebut menantang pikiran (chalenging); dan b) Soal tersebut tidak otomatis diketahui cara penyelesaiannya (nonrutin).

Memacahkan masalah berarti menemukan seluruh kemungkinan logis dalam mencari jawaban suatu masalah. Ollerton (2007) menyebutkan bahwa terdapat 5 kriteria yang harus terjadi dalam menerapkan situasi pemecahan masalah, yaitu:

a. Sebuah masalah harus dapat mengembangkan pengetahuan siswa.

b. Siswa memiliki pengetahuan dasar dalam menyelesaikan masalah, namun dalam waktu yang sama belum dapat menyelesaiakan masalah dengan cara seperti yang sudah diketahui.

c. Menggunakan lebih banyak pertanyaan terbuka.

d. Untuk mengetahui perbedaaan pemahaman siswa masalah perlu diperluas.

e. Membantu perkembangan kemandirian belajar siswa.

Beck (2005:21) menyebutkan bahwa permasalahan matematika dapat menjadi berbeda antara satu dengan yang lainnya tergantung pada tingkatan "keterbukaannya", yaitu:

a. Soal tertutup: soal dengan satu jawaban benar dan satu cara penyelesaian.

b. Soal setengah terbuka: soal dengan satu jawaban benar tetapi dapat dicari dengan berbagai cara penyelesaian.

c. Soal terbuka: soal dengan beberapa jawaban benar dan dengan beberapa cara penyelesaian.

Dari pembahasan di atas dapat disimpulkan bahwa soal yang termasuk dalam soal pemecahan masalah siswa adalah: Soal tidak otomatis diketahui cara penyelesaiannya (nonrutin), soal terbuka (soal yang jawabannya lebih dari satu), soal terjangkau dan menantang siswa untuk dikerjakan. Dalam menyelesaikan masalah matematika masih banyak siswa yang mengalami kesulitan. Aljabar dan trigonometri memiliki dua bahan kajian yaitu Aljabar dan Trigonometri sehingga mahasiswa juga masih kesulitan dalam menyelesaikan soal pemecahan masalah terkait mata kuliah ini. Menurut Mulyadi (2010:74), kesulitan belajar siswa disebut juga diskalkulia. Istilah diskalkulia memiliki kondisi medis yang memandang adanya keterkaitan dengan gangguan system syaraf pusat, Gangguan Matematika adalah suatu ketidakmampuan dalam keterampilan matematika yang diharapkan untuk kapasitas intelektual dan pendidikan seseorang. Masih banyak siswa yang mengalami kesulitan-kesulitan dalam mengerjakan soal-soal Matematika.

Menurut Utami (2012:5) jenis-jenis kesulitan belajar matematika meliputi: 1) kesulitan penggunaan konsep, indikator kesulitan penggunaan konsep adalah siswa mampu menandai, mengungkapkan dengan kata-kata dan mengidentifikasi konsep serta mengungkapkan model; 2) kesulitan penggunaan prinsip, indikator kesulitan penggunaan prinsip adalah siswa mampu memberikan alasan pada langkah-langkah penggunaan 
prinsip, mengeneralisasi prinsip yang benar dan memodifikasi suatu prinsip, 3) kesulitan dalam mengungkapkan informasi, 4) kesulitan berhitung.

\section{METODE}

Penelitian ini merupakan Penelitian deskriptif kualitatif. Penelitian kualitatif (Qualitatif research) yaitu suatu penelitian yang ditujukan untuk mendeskripsikan dan menganalisis fenomena, peristiwa, aktivitas sosial, sikap, kepercayaan, persepsi, pemikiran orang secara individual maupun kelompok Sudjana, (2015:60). Sedangkan sifat penelitian yang akan dilakukan adalah bersifat deskriptif. Tujuan penelitian deskriptif untuk menyelidiki keadaan, kondisi atau hal-hal lain yang sudah disebutkan yang hasilnya dipaparkan dalam bentuk laporan penelitian (Suharsimi, 2013:3). Penelitian dilaksanakan di program studi pendidikan Matematika Universitas Katolik Santo Thomas Sumatera Utara di Jalan Setia Budi No. 479-F Tanjung Sari-Medan semester ganjil tahun pembelajaran 2017/2018. Sumber data pada penelitian ini adalah mahasiswa semester 1 Prodi Pendidikan Matematika FKIP Universitas Katolik Santo Thomas Sumatera Utara tahun pembelajaran 2017/2018 yang berjumlah 10 orang mahasiswa dengan komposisi 9 orang mahasiwa laki-laki dan 1 orang mahasiswa perempuan.

Data yang akan dianalisis dalam penelitian ini adalah data hasil observasi pembelajaran mahasiswa semester 1 Pendidikan Matematika Unika Santo Thomas tahun ajaran 2017/2018 yang dilakukan oleh peneliti. Observasi ini bertujuan untuk melihat kondisi pada saat pembelajaran, melihat karakter mahasiswa, dan mengetahui faktor yang menyebabkan mahasiswa mengalami kesulitan belajar mata kuliah Aljabar dan Trigonometri.

Data selanjutnya adalah hasil jawaban tes mahasiswa dalam menyelesaikan soal-soal pemecahan masalah pada mata kuliah Aljabar dan Trigonometri. Data tersebut berupa jawaban uraian mahasiswa yang meliputi langkah-langkah dalam menyelesaikan soal-soal Aljabar dan Trigonometri. Data tersebut kemudian akan dianalisis untuk mengetahui letak kesulitan mahasiswa. Selanjutnya adalah data hasil wawancara, wawancara dilakukan setelah hasil jawaban selesai dianalisis. Tujuannya adalah untuk mengkonfirmasi dan mempertajam hasil dari jawaban tes yang dikerjakan mahasiswa. Serta untuk mendapatkan informasi mengenai faktor penyebab mahasiswa melakukan kesalahan dalam menyelesaikan soal yang dapat mengindikasikan bahwa mahasiswa tersebut mengalami kesulitan dalam menyelesaikan soal Aljabar dan Trigonometri.

Teknik pengumpulan data dalam penelitian ini adalah (1) Teknik observasi, teknik observasi adalah cara pengumpulan data dimana peneliti melakukan pengumpulan terhadap subyek penelitian. (2) Tes tertulis, digunakan untuk mengetahui tingkat kesulitan penggunaan konsep, kesulitan penggunaan prinsip, kesulitan mengungkapkan informasi dan kesulitan berhitung yang dilami oleh mahasiswa dalam menyelesaikan soal-soal Aljabar dan Trigonometri. (3) Teknik wawancara, tujuan dari wawancara ini adalah untuk mengkonfirmasi dan mempertajam hasil dari jawaban tes yang dikerjakan mahasiswa, serta untuk mendapatkan informasi mengenai factor penyebab mahasiswa melakukan kesalahan dalam menyelesaikan soal Aljabar dan Trigonometri (4) Teknik dokumentasi, dokumentasi dalam penelitian ini dilakukan untuk memperkuat data yang diperoleh dalam observasi.

\section{HASIL DAN PEMBAHASAN Hasil}

Tes yang diberikan kepada mahasiswa terdiri dari dua kali tes dalam hal ini tes pada saat ujian tengah semseter untuk materi Aljabar dan ujian akhir semester untuk materi Trigonometri. Berikut adalah hasil analisis data hasil tes materi aljabar dan Trigonometri: 
Analisis Data Hasil Tes

Hasil uraian jawaban mahasiswa terhadap lima soal pemecahan masalah Materi Aljabar dianalisis dan kemudian diperoleh hasilnya sebagai berikut:

Tabel 1. Rangkuman Uraian Jawaban Mahasiswa terhadap Lima Soal Pemecahan Masalah Materi Aljabar

\begin{tabular}{|c|c|c|}
\hline No & Soal & Keterangan \\
\hline 1 & $\begin{array}{l}\text { Uang sebanyak Rp. } \\
\text { 3.000.000,00 akan dibagikan } \\
\text { kepada A dan B. Jika A } \\
\text { memperoleh Rp. 750.000,00 } \\
\text { lebih banyak daripada B, } \\
\text { berapa banyaknya uang yang } \\
\text { diperoleh A dan B masing- } \\
\text { masing? }\end{array}$ & $\begin{array}{l}\text { Berdasarkan analisis yang telah dilakukan } \\
\text { terhadap seluruh jawaban mahasiswa diperoleh } \\
\text { hasil bahwa kesulitan penggunaan konsep } \\
\text { dialami oleh } 4 \text { orang mahasiswa, kesulitan } \\
\text { penggunaan prinsip dialami } 1 \text { mahasiswa, } \\
\text { kesulitan kemampuan mengungkapkan } \\
\text { informasi dialami } 3 \text { mahasiswa dan kesulitan } \\
\text { berhitung oleh } 0 \text { mahasiswa. }\end{array}$ \\
\hline 2 . & $\begin{array}{l}\text { Tentukan jumlah seratus } \\
\text { bilangan asli pertama. } \\
1+2+3+4+\ldots \ldots \ldots+98+ \\
99+100\end{array}$ & $\begin{array}{l}\text { Berdasarkan analisis yang telah dilakukan } \\
\text { terhadap seluruh jawaban mahasiswa diperoleh } \\
\text { hasil bahwa kesulitan penggunaan konsep } \\
\text { dialami oleh } 4 \text { orang mahasiswa, kesulitan } \\
\text { penggunaan prinsip dialami } 3 \text { mahasiswa, } \\
\text { kesulitan kemampuan mengungkapkan } \\
\text { informasi dialami 0 mahasiswa dan kesulitan } \\
\text { berhitung oleh } 1 \text { mahasiswa. }\end{array}$ \\
\hline 3. & $\begin{array}{l}\text { Budi dan Ari berencana } \\
\text { untuk makan di warung Pak } \\
\text { Badu dan pergi latihan } \\
\text { basket bersama. Latihan } \\
\text { basket dimulai pukul } 11.00 \text {. } \\
\text { Bagas memerlukan waktu } 1 \\
1 / 4 \text { jam untuk menjemput } \\
\text { Soni dan pergi ke warung } \\
\text { Pak Badu dekat lokasi } \\
\text { latihan softball. Untuk } \\
\text { makan dan berjalan ke lokasi } \\
\text { latihan diperlukan waktu } 1 \\
\text { jam. Mereka ingin tiba di } \\
\text { lokasi latihan } 15 \text { menit } \\
\text { sebelum di mulai. Pukul } \\
\text { berapa Budi seharusnya } \\
\text { meninggalkan rumahnya? }\end{array}$ & $\begin{array}{l}\text { Berdasarkan analisis yang telah dilakukan } \\
\text { terhadap seluruh jawaban mahasiswa diperoleh } \\
\text { hasil bahwa kesulitan penggunaan konsep } \\
\text { dialami oleh } 3 \text { orang mahasiswa, kesulitan } \\
\text { penggunaan prinsip dialami } 3 \text { mahasiswa, } \\
\text { kesulitan kemampuan mengungkapkan } \\
\text { informasi dialami } 2 \text { mahasiswa dan kesulitan } \\
\text { berhitung oleh } 2 \text { mahasiswa. }\end{array}$ \\
\hline 4. & $\begin{array}{l}\text { Lima tahun yang lalu jumlah } \\
\text { umur seorang ibu beserta } \\
\text { anak kembarnya adalah } 40 \\
\text { tahun. Jika pada saat itu } \\
\text { umur ibunya } 30 \text { tahun, } \\
\text { berapa tahunkah umur anak } \\
\text { kembarnya sekarang? }\end{array}$ & $\begin{array}{l}\text { Berdasarkan analisis yang telah dilakukan } \\
\text { terhadap seluruh jawaban mahasiswa diperoleh } \\
\text { hasil bahwa kesulitan penggunaan konsep } \\
\text { dialami oleh } 2 \text { orang mahasiswa, kesulitan } \\
\text { penggunaan prinsip dialami } 3 \text { mahasiswa, } \\
\text { kesulitan kemampuan mengungkapkan } \\
\text { informasi dialami } 1 \text { mahasiswa dan kesulitan } \\
\text { berhitung oleh } 1 \text { mahasiswa. }\end{array}$ \\
\hline 5 . & $\begin{array}{lcr}\text { Panjang } & \text { suatu } & \text { persegi } \\
\text { panjang diketahui } & (2 \mathrm{x}-5) \mathrm{cm}\end{array}$ & $\begin{array}{l}\text { Berdasarkan analisis yang telah dilakukan } \\
\text { terhadap seluruh jawaban mahasiswa diperoleh } \\
\text { hasil bahwa kesulitan penggunaan konsep }\end{array}$ \\
\hline
\end{tabular}


Analisis Kesulitan Mahasiswa dalam Menyelesaikan Soal Pemecahan...

dan lebarnya $(3 x+1)$. dialami oleh 2 orang mahasiswa, kesulitan

Tentukan :
a. Keliling
panjang
persegi dinyatakan dalam $\mathrm{x}$ yang
b. Ukuran persegi
panjang, jika
kelilingnya $23 \mathrm{~cm}$ penggunaan prinsip dialami 1 mahasiswa, penggunaan prinsip dialami 1 mahasiswa,

Hasil uraian jawaban mahasiswa terhadap lima soal pemecahan masalah materi Trigonometri dianalisis dan kemudian diperoleh hasilnya sebagai berikut:

Tabel 2. Rangkuman Uraian Jawaban Mahasiswa terhadap Lima Soal Pemecahan Masalah Materi Trigonometri

\begin{tabular}{|c|c|c|}
\hline No & Soal & Keterangan \\
\hline 1 & $\begin{array}{l}\text { Jika } \frac{2 \tan x}{1-\tan ^{2} x}-2=0 \text { dengan } \\
0<x<180 \text { maka Tentukan nilai } \\
\cos ^{2} x-\sin ^{2} x\end{array}$ & $\begin{array}{l}\text { Berdasarkan analisis yang telah dilakukan } \\
\text { terhadap seluruh jawaban mahasiswa } \\
\text { diperoleh hasil bahwa kesulitan } \\
\text { penggunaan konsep dialami oleh } 3 \text { orang } \\
\text { mahasiswa, kesulitan penggunaan prinsip } \\
\text { dialami } 5 \text { mahasiswa, kesulitan } \\
\text { kemampuan mengungkapkan informasi } \\
\text { dialami 0 mahasiswa dan kesulitan } \\
\text { berhitung oleh } 0 \text { mahasiswa. }\end{array}$ \\
\hline 2. & $\begin{array}{l}\text { Tentukan nilai x yang memenuhi } \\
\text { persamaan } \\
(\cos 3 x+\tan 3 x)(\cos 3 x-\tan 3 x)=1 \\
\text { untuk } 0 \leq x \leq 360, x \neq \frac{\pi}{6}+\frac{2 k \pi}{3} \\
\text { dan k bilangan asli. }\end{array}$ & $\begin{array}{l}\text { Berdasarkan analisis yang telah dilakukan } \\
\text { terhadap seluruh jawaban mahasiswa } \\
\text { diperoleh hasil bahwa kesulitan } \\
\text { penggunaan konsep dialami oleh } 3 \text { orang } \\
\text { mahasiswa, kesulitan penggunaan prinsip } \\
\text { dialami } 2 \text { mahasiswa, kesulitan } \\
\text { kemampuan mengungkapkan informasi } \\
\text { dialami } 1 \text { mahasiswa dan kesulitan } \\
\text { berhitung oleh } 1 \text { mahasiswa. }\end{array}$ \\
\hline 3. & $\begin{array}{l}\text { Simpangan suatu partikel yang } \\
\text { bergerak di sekitar titik tetap O } \\
\text { dinyatakan sebagai } \mathrm{y}=4 \sin ^{2} \mathrm{t} \text {. } \\
\text { Jika } \cos ^{2} t-\sin ^{2} t=\cos 2 \mathrm{t} \text {, maka } \\
\text { nyatakan simpangan partikel } \\
\text { tersebut dalam bentuk } \cos 2 \mathrm{t} \text {. }\end{array}$ & $\begin{array}{l}\text { Berdasarkan analisis yang telah dilakukan } \\
\text { terhadap seluruh jawaban mahasiswa } \\
\text { diperoleh hasil bahwa kesulitan } \\
\text { penggunaan konsep dialami oleh } 4 \text { orang } \\
\text { mahasiswa, kesulitan penggunaan prinsip } \\
\text { dialami } 4 \text { mahasiswa, kesulitan } \\
\text { kemampuan mengungkapkan informasi } \\
\text { dialami 0 mahasiswa dan kesulitan } \\
\text { berhitung oleh } 1 \text { mahasiswa. }\end{array}$ \\
\hline 4. & $\begin{array}{l}\text { Diketahui sebuah segitiga } A B C \\
\text { mempunyai panjang sisi } A C=b \\
\mathrm{~cm}, \mathrm{BC}=\mathrm{a} \mathrm{cm} \text { dan } \mathrm{a}+\mathrm{b}=12 \mathrm{~cm} \text {. } \\
\text { Jika sudut A sebesar } 60^{\circ} \text { dan sudut } \\
\mathrm{B} \text { sebesar } 30^{\circ} \text {. Tentukan panjang } \\
\text { sisi } \mathrm{AB} \text {. }\end{array}$ & $\begin{array}{l}\text { Berdasarkan analisis yang telah dilakukan } \\
\text { terhadap seluruh jawaban mahasiswa } \\
\text { diperoleh hasil bahwa kesulitan } \\
\text { penggunaan konsep dialami oleh } 5 \text { orang } \\
\text { mahasiswa, kesulitan penggunaan prinsip } \\
\text { dialami } 4 \text { mahasiswa, kesulitan } \\
\text { kemampuan mengungkapkan informasi } \\
\text { dialami 0 mahasiswa dan kesulitan } \\
\text { berhitung oleh } 1 \text { mahasiswa. }\end{array}$ \\
\hline
\end{tabular}



5. Tentukan himpunan penyelesaian pertidaksamaan $2 \tan x-\sqrt{3}>0$ untuk $0 \leq x \leq 360$.

Berdasarkan analisis yang telah dilakukan
terhadap seluruh jawaban mahasiswa
diperoleh hasil bahwa
penggunaan konsep dialami oleh 1 orang
mahasiswa, kesulitan penggunaan prinsip
dialami 1 mahasiswa, kesulitan
kemampuan mengungkapkan informasi
dialami 0 mahasiswa dan kesulitan
berhitung oleh 0 mahasiswa.

Persentase Hasil Tes

Hasil analisis kemudian dihitung persentasenya berdasarkan jenis kesalahan yang dilakukan oleh mahasiswa pada materi Aljabar sebagai berikut:

Tabel 3. Persentase Kesalahan Jawaban pada Materi Aljabar

\begin{tabular}{|c|c|c|c|c|c|c|c|}
\hline \multirow[t]{2}{*}{ Jenis Kesalahan } & \multicolumn{5}{|c|}{$\begin{array}{c}\text { Jumlah Kesalahan (orang) } \\
\text { pada Soal Nomor ke- }\end{array}$} & \multirow[t]{2}{*}{ Jumlah } & \multirow[t]{2}{*}{ Persentase } \\
\hline & 1 & 2 & 3 & 4 & 5 & & \\
\hline $\begin{array}{l}\text { Penggunaan } \\
\text { Konsep }\end{array}$ & 4 & 4 & 3 & 2 & 2 & 15 & $42.85 \%$ \\
\hline $\begin{array}{l}\text { Penggunaan } \\
\text { Prinsip }\end{array}$ & 1 & 2 & 3 & 3 & 1 & 10 & $28.57 \%$ \\
\hline $\begin{array}{l}\text { Kemampuan } \\
\text { Mengungkapkan } \\
\text { informasi }\end{array}$ & 3 & 0 & 2 & 1 & 0 & 6 & $17.14 \%$ \\
\hline Berhitung & 0 & 1 & 2 & 1 & 0 & 4 & $11.42 \%$ \\
\hline
\end{tabular}

Hasil analisis kemudian dihitung persentasnya berdasarkan jenis kesalahan yang dilakukan oleh mahasiswa pada materi Trigonometri sebagai berikut:

Tabel 4. Persentase Kesalahan Jawaban pada Materi Trigonometri

\begin{tabular}{|c|c|c|c|c|c|c|c|}
\hline \multirow{2}{*}{ Jenis Kesalahan } & \multicolumn{5}{|c|}{$\begin{array}{c}\text { Jumlah Kesalan (orang) pada Soal } \\
\text { Nomor ke- } \\
\end{array}$} & \multirow{2}{*}{ Jumlah } & \multirow{2}{*}{ Persentase } \\
\hline & 1 & 2 & 3 & 4 & 5 & & \\
\hline $\begin{array}{l}\text { Penggunaan } \\
\text { Konsep }\end{array}$ & 3 & 3 & 4 & 5 & 1 & 15 & $44.11 \%$ \\
\hline Penggunaan Prinsip & 5 & 2 & 4 & 4 & 1 & 15 & $44.11 \%$ \\
\hline $\begin{array}{l}\text { Kemampuan } \\
\text { Mengungkapkan } \\
\text { informasi }\end{array}$ & 0 & 1 & 0 & 0 & 0 & 1 & $2.94 \%$ \\
\hline Berhitung & 0 & 1 & 1 & 1 & 0 & 3 & $8.82 \%$ \\
\hline
\end{tabular}

\section{Pembahasan}

Pembelajaran pada Mata kuliah Aljabar dan Trigonometri dilakukan dengan menerapkan metode pembelajaran Problem Solving. Pembelajaran ini melatih mahasiswa untuk mampu memecahkan masalah matematika. Dalam pembelajaran metode problem solving dilakukan dengan mengikuti langkah-langkah pemecahan masalah Polya yaitu menuliskan seluruh informasi, membuat rencana, melaksanakan sesuai rencana dan memeriksa kembali. Berdasarkan langkah-langkah penyelesaian masalah dengan Polya ini, mahasiswa terbantu dalam memecahkan masalah Aljabar dan Trigonometri. Mahasiswa diajari setiap tahap dalam menyelesaikan masalah matematika. Berdasarkan observasi, pada saat pembelajaran dapat disimpulkan bahwa mahasiswa sangat antusias dan sangat senang dalam menerapkan metode problem solving karena mereka dilatih untuk memahami 
masalah, membuat rencana penyelesaian, melaksanakan rencana dan memeriksa kembali apa yang sudah dikerjakan pada tahap sebelumnya. Namun, dalam mengerjakan soal-soal pemecahan masalah masih ditemukan kesalahan-kesalahan yang dilakukan mahasiswa yang mengindikasikan adanya kesulitan mahasiswa dalam menyelesaikan soal pemecahan masalah pada mata kuliah Aljabar dan Trigonometri.

Berdasarkan analisis yang dilakukan terhadap data-data yang diperoleh dari hasil penelitian, maka peneliti mengambil kesimpulan bahwa mahasiswa mengalami kesulitan pada saat menyelesaikan soal-soal Aljabar dan Trigonometri. Diperoleh fakta bahwa mahasiswa mengalami kesulitan dalam menyelesaikan soal-soal pemecahan masalah yaitu pada penggunaan konsep, penggunaan prinsip, kemampuan mengungkapkan informasi, dan berhitung. Hal ini sejalan dengan penelitian Nurjanah mengalami kesulitan dalam menyelesaikan soal-soal program linear yaitu pada penggunaan konsep, penggunaan prinsip, kemampuan mengungkapkan informasi, dan berhitung.

Beberapa faktor penyebab adanya kesulitan yang dialami siswa dalam menyelesaikan soal pemecahan masalah pada materi Trigonometri diantaranya adalah factor intern yaitu faktor yang berasal dari dalam diri siswa yaitu kemampuan matematika mahasiswa masih kurang hal ini dapat dilihat ketika mengerjakan soal-soal pada saat pembelajaran, dimana mahasiswa masih kesulitan dan selalu bertanya tentang penyelesaian soal yang diberikan. Faktor penyebab kesulitan yang kedua adala faktor ekstern yaitu factor yang berasal dari luar diri siswa. Beberapa siswa selama pembelajaran terlihat tidak fokus karena masalah kesehatan dimana pembelajaran dimulai di jam pagi dan ada beberapa mahasiswa yang masih belum serapan sehingga mempengaruhi konsentrasi dalam belajar da nada beberapa mahasiswa yang tidak memiliki semangat dan motivasi dalam belajar.

\section{KESIMPULAN}

Temuan penelitian, hasil analisis data, perangkat pembelajaran, maupun instrumen yang dihasilkan dalam penelitian ini dapat dijadikan referensi dalam menganalisis kesulitan-kesulitan mahasiswa dalam menyelesaikan soal pemecahan masalah pada pada mata kuliah Aljabar dan Trigonometri.

Bagi dosen yang mengajar mata kuliah Aljabar dan Trigonometri: (1) memberikan soal pemecahan masalah pada mata kuliah Aljabar dan Trigonometri untuk melatih kemampuan pemecahan masalah matematika mahasiswa (2) Memahami benar-benar langkah-langkah pemecahan masalah matematika, (3) Melatih mahasiswa untuk menggunkaan konsep, menggunakan prinsip, menuliskan informasi dari soal dan melatih perhitungan untuk mengurangi kesulitan-kesulitan belajar matematika pada mata kuliah aljabar dan trigonometri, serta (4) Melibatkan semua mahasiswa agar berinteraksi secara positif, diawali dari masalah yang diberikan dosen.

\section{DAFTAR PUSTAKA}

Beck, Pam. 2005.Mathematics Assesment a practical Handbook for grades 6-8. USA: NCTM.

Shadiq, F. 2009. Sistem Pembinaan dan Karakteristik Soal Olimpiade Matematika. Yogyakarta: PPPPTK Matematika.

Mulyadi. 2010. Diagnosis Kesulitan Belajar dan Bimbingan terhadap Kesulitan Belajar Khusus. Yogyakarta: Nuha Litera.

Sudjana, N. 2015. Penilaian Hasil Proses Belajar Mengajar. Bandung: PT. Remaja Rosdakarya.

Ollerton, M. 2007. Teaching and Learning through Problem Solving. ProQuest Education Journals. 201(3). 
Vol. 4, No. 1. Oktober 2018

Utami, W. T. 2012. Identifikasi Kesulitan dalam menyelesaikan Persoalan Matematika yang berkaitan dengan Pecahan di kelas VIII SMP N 3 Ngaglik Sleman tahun Ajaran 2011/2012. Yogyakarta: Universitas Negeri Yogyakarta. 